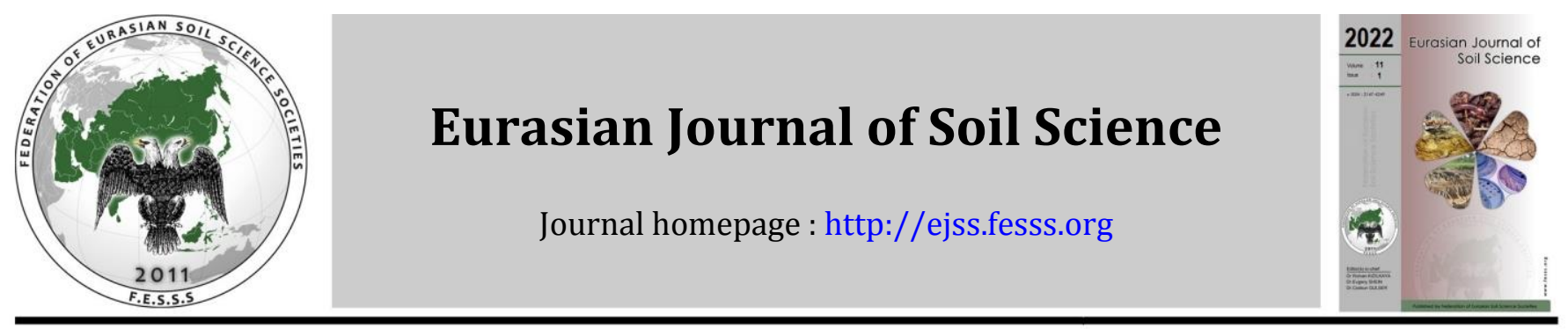

\title{
A review on nanobioremediation approaches for restoration of contaminated soil
}

\author{
Vishnu D. Rajput a*, Tatiana Minkina a, Arpna Kumari a, Sudhir S. Shende a, \\ Anuj Ranjan a, Mohammad Faizan b, Anatoly Barakvov a, Arkadii Gromovik e, \\ Nadezhda Gorbunova e, Priyadarshani Rajput a, Abhishek Singh c, Ilgiz Khabirov d, \\ Olga Nazarenko f, Svetlana Sushkova a, Ridvan Kizılkaya $\mathrm{g}$ \\ a Southern Federal University, Stachki 194/1, Rostov-on-Don, 344090, Russia \\ b Nanjing Forestry University, Nanjing -210037, China \\ c Sardar Vallabhbhai Patel University of Agriculture and Technology, Meerut, U.P., India \\ d Bashkir State Agrarian University, Ufa 450001, Russia \\ eVoronezh State University, Voronezh, 394018, Russia \\ f Agrochemical center "Rostovsky", Aksay district, Rostov region, 346735, Russia \\ g Ondokuz Mayıs Üniversity, Faculty of Agriculture, Department of Soil Science and Plant Nutrition, Samsun, Turkey
}

\section{Article Info}

Received : 19.02.2021

Accepted : 29.08.2021

Available online : 03.09.2021

\section{Author(s)}

V.D.Rajput *

T.Minkina

A.Kumari

S.S.Shende

A.Ranjan

M.Faizan

A.Barakvov

A.Gromovik

N.Gorbunova

P.Rajput

A.Singh

I.Khabirov

O.Nazarenko

S. Sushkova

R.Kızılkaya

* Corresponding author

\begin{abstract}
Nanotechnological approaches are emerging as one of the most contemporary restoration strategies that may be used to remove a variety of contaminants from the environment, including heavy metals, organic and inorganic pollutants. The application of nanoparticles (NPs) is entrenched with biological processes to boost up the removal of toxic compounds from contaminated soils. Many efforts have been taken to increase the effectiveness of phytoremediation such as the addition of chemical additives, application of rhizobacteria, and genetic engineering, etc. In this context, the integration of nanotechnology with bioremediation has introduced new dimensions to the reclamation methods. Thus, advanced remediation methods that combine nanotechnology with phytoremediation and bioremediation, where nanoscale process regulation aids in the absorption and breakdown of pollutants. NPs absorb/adsorb a variety of contaminants and also catalyze reactions by lowering the energy required for their breakdown due to unique surface properties. As a result, these nanobioremediation procedures decrease the accumulation of contaminants while simultaneously limiting their dispersal from one medium to another. Therefore, the present review is dealing with all the possibilities of the application of NPs for restoration of contaminated soils.
\end{abstract}

Keywords: Phytoremediation potential, phytorestoration strategy, NPs, contaminated soils, plants, microorganisms.

(C) 2022 Federation of Eurasian Soil Science Societies. All rights reserved

\section{Introduction}

Soil is the essence of agriculture and it is enriched with vital macro and micronutrients that promote healthy growth of the crops that ultimately impart health benefits to humans (Joshi et al., 2020). Several anthropogenic activities contaminate the soil with a load of synthetic organic compounds, heavy metals, agrochemicals, and an excess of nutrients as well (Minkina et al., 2019; Ghazaryan et al., 2020). Similarly,

https://doi.org/10.18393/ejss.990605

http://ejss.fesss.org/10.18393/ejss.990605 
industrialization/urbanization is adding solid wastes, chemicals and solvents, and other persistent organic and inorganic materials to different environmental matrices (Midhat et al., 2019).

Advancement in nanotechnology and nanoscience provide new directions to research and development in almost every field of science. It is an expanding research field that involves structures, devices, and systems with unique properties owing to the arrangement of their atoms at the nanoscale (1-100 nm) (Bayda et al., 2019; Rajput et al., 2020b; 2021b). In recent decades, nanotechnology has been used in a range of contexts, notably medicine, textiles, pharmaceutics, electronics, optics, cosmetics, sports, and many others. The application of NPs in agriculture was accepted at the beginning of the twenty-first century (Fraceto et al., 2016), and more than 232 products are available for various agricultural uses (Rajput et al., 2021a). Also, it has not remained static in the field of environmental restoration (Guerra et al., 2018; Singh et al., 2020).

Recently, nanobioremediation (NBR) is declared as a technology for cleaning up environmental contamination by accelerating natural biodegradation processes using NPs. NBR is defined as a process that uses NPs with microorganisms, or plants to eradicate hazardous contaminants from the soils (Cecchin et al., 2017). Following that, distinct NBR procedures are defined based on the type of organism used for contaminants remediation (i.e., nanophytoremediation, and microbial nanoremediation (Burachevskaya et al., 2020; Rajput et al., 2020a,c; Singh et al., 2020; Kumari et al., 2021). The intensification in the expenses of chemical as well as physical processes, microbes- and plant-mediated NBR technologies are receiving more attention.

Coming to the benefits of NBR, there is a multitude of reasons why nanotechnology is integrated with bioremediation. For example, NPs have a large surface area per unit mass, which means that a greater number of particles can come into contact with the environment, boosting the remediation process (Fernández-Luqueño et al., 2018; Kaur et al., 2018). Thus, NBR efforts to minimize pollutant concentrations to risk-based thresholds while also decreasing secondary environmental impacts. Furthermore, this method of reclamation also combines the advantages of nanotechnology and bioremediation to create a remediation process that is more efficient, faster, and environmentally benign than the individual methods (Patil et al., 2016; Kumar et al., 2021).

However, every advance of the process of remediation has particular explicit merits as well as demerits that need to be taken into consideration for each location. In a nutshell, after the extensive literature survey, it can be concluded that integration of bioremediation with nanotechnology appears to be a feasible alternative to conventional remediation technologies either in sequence or in parallel to them. However, there are still more studies and development measures necessary to bring these types of sustainable technology to the market for full implementation.

\section{Recent advances in bioremediation of polluted soil}

Chemical and physical remediation, incineration, and bioremediation are some of the NBR technologies that are currently in use. With recent advances, NBR provides an environmentally friendly and economically viable option for removing contaminants (Patra Shahi et al., 2021). The fundamental principle behind the NBR is depicted as the degradation of organic wastes employing nano-catalysts as a medium that allows them to enter deep within contaminants, thereby executes the whole process safely without modulating the environment (Rizwan et al., 2014; Cecchin et al., 2017; Chauhan et al., 2020). The overview of NBR is presented in figure 1.

As bioremediation relies on live species to clean up contaminated environments, thereby a good relationship between NPs and living organisms is critical for the efficacy of this phenomenal technique (Sangwan and Dukare, 2018; Paterlini et al., 2021). In this context, it is documented that the physical and chemical interactions between NPs, biota, and contaminants are influenced by numerous factors viz., NPs' size and shape, surface coating, and chemical nature. Plus, the nature of contaminants, the type of organism used, the media, $\mathrm{pH}$, and temperature are also recorded to impact the process considerably (Ibrahim et al., 2016; Tan et al., 2018).

These events grow complicated due to the large number of potential parameters that have a direct or indirect influence on such interactions. For example, temperature and $\mathrm{pH}$ of media are reported as important factors for the optimal development of biological organisms (Patra and Baek, 2014). Now pinpointing the different actions, such as dissolution, absorption, and biotransformation may occur when NPs and biota interact (Kranjc and Drobne, 2019; Vázquez-Núñez et al., 2020). On the other hand, interactions of NPs and biota can be toxic or stimulating which results in a biocidal or bio-stimulant effect, 
thus the performance of organisms involved in the NBR process could be impacted (Juárez-Maldonado et al., 2019).

Some of the most important NPs used in NBR are nano-iron, nanosized dendrimers, carbon nanotubes, single enzyme NPs, engineered NPs, etc. (Kaur et al., 2018; Patra Shahi et al., 2021). In the NBR technique, the contaminants are first broken down by NPs to a level that is conducive to biodegradation, and then the contaminants are biodegraded. The main advantages of bioremediation over conventional strategies are high competency, reduced generation of chemical and biological wastes, selectivity, no additional nutrient requirements, bio-sorbent regeneration, the probability of metal recovery, etc. (Juwarkar et al., 2010; Rizwan et al., 2014; Chauhan et al., 2020).

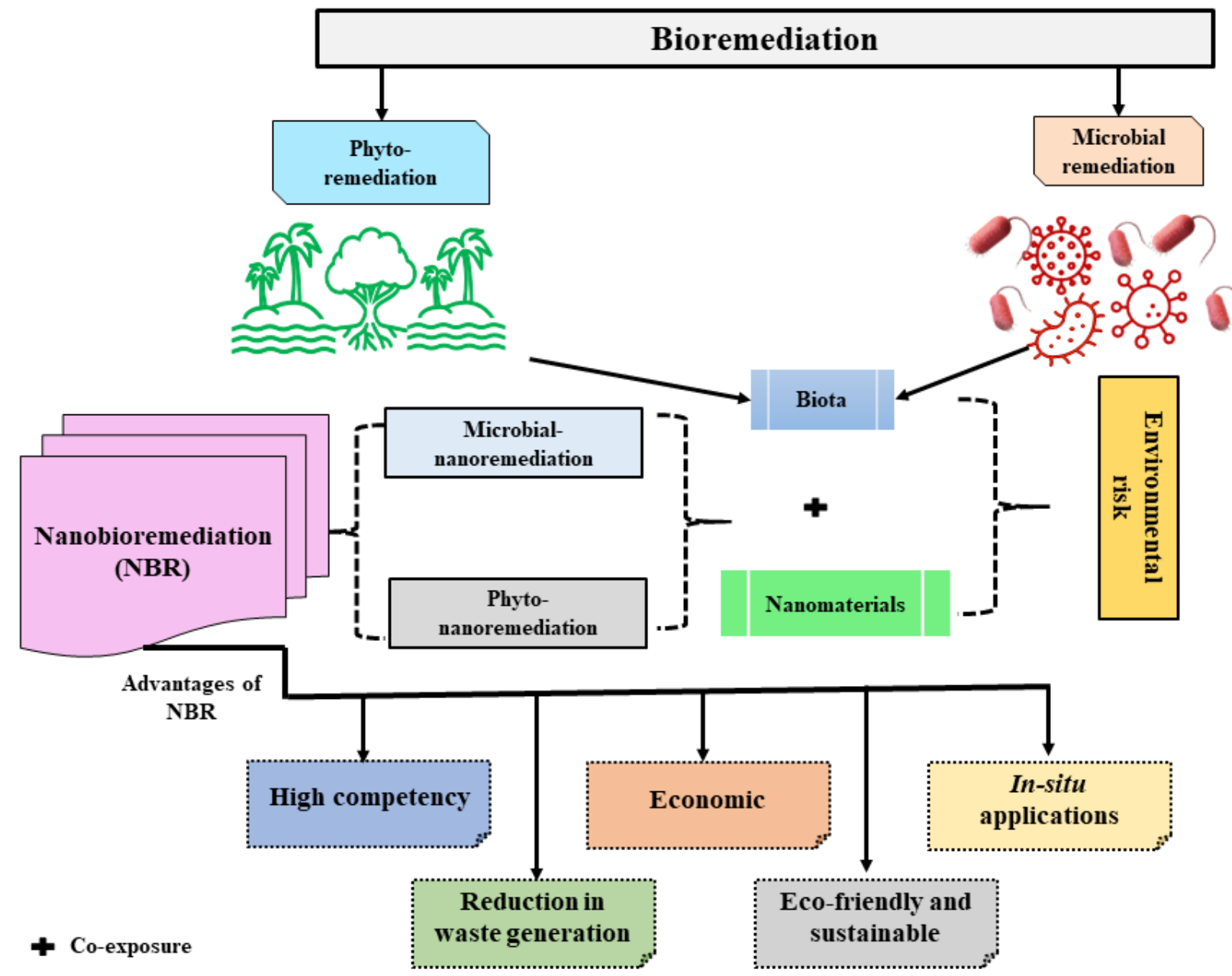

Figure 1. The pictorial representation of nanobioremediation and its types along with environmental risks

On top of it, most currently available conventional remediation procedures are based on the classic ex-situ strategy, which entails excavating contaminated material and then treating them with conventional means. Plus, some of these processes are energy-intensive, which makes them expensive, and they may also leave concentrated hazardous waste residues that require additional treatment and disposal (Wuana and Okieimen, 2011; Chauhan et al., 2020). On the flip side, in-situ remediation methods benefit greatly from the peculiar characteristics of NPs (Kumari et al., 2021; Rajput et al., 2021b). Thus, in-situ NBR can annihilate the need for draining out of groundwater and transportation of contaminated soils to treatment and disposal sites.

\section{Nanophytoremediation of polluted soils}

Nano-encapsulated enzymes also have greater potential in treating some complex organic pollutants, for example, persistent pesticides (organochlorines) and long-chain hydrocarbons are hard to degrade by microbial or plant remediation process (Chauhan et al., 2020). Few successful field applications of NPs have been done in past for the bioremediation of soils.

\section{Heavy metals}

Heavy metal pollution of arable soils is an increasing problem, as it poses a serious threat to food safety, public health, and the food chain and ecosystem. For in-situ treatment of polluted soils, phytoremediation is 
documented as a favored and cost-effective method by researchers (Liang et al., 2017). Phytoremediation of soils polluted with cadmium, chromium, lead, nickel, and zinc was improved with the introduction of NPs, according to several studies (Wani et al., 2017; Ekta and Modi, 2018; Kanwar et al., 2020). It is a wellestablished that exposure to heavy metal pollutants has major health risks to the well-being of humans (Rajput et al., 2020d; Zamani et al., 2020).

Phytoextraction is the most familiar method adopted to eliminate heavy metals from polluted soil (Ali et al., 2013). The application of NPs to enhance the phytoextraction efficiency has been a successful strategy towards nanophytoremediation (Ebbs and Kochian, 1998; Ghazaryan et al., 2018; Ghazaryan et al., 2019). Iron NPs are used as a strong reductant for those pollutants that require a reduction process for degradation (Sun et al., 2006), whereas, zerovalent iron (nZVI) has great potential in phytoremediation of a range of pollutants as it is a highly reactive reducing agent. Plants treated with the lower concentrations (100-500 $\mathrm{mg} / \mathrm{kg}$ ) of nZVI have exhibited the maximum accumulation (1175.40 g per pot with $100 \mathrm{mg} / \mathrm{kg}$ of nZVI). Whereas, a higher dose of nZVI NPs (500-1000 mg/kg) caused oxidative stress in Lolium perenne thereby reducing the uptake of $\mathrm{Pb}$ (Huang et al., 2018). Another study reports the similar characteristics of nZVI of concentration $100-500 \mathrm{mg} / \mathrm{kg}$ that improves $\mathrm{Pb}$ uptake up to $857.18 \mu \mathrm{g}$ per pot (at $500 \mathrm{mg} / \mathrm{kg}$ ) in the ragweed (Kochia scoparia also known as Bassia scoparia).

The $\mathrm{TiO}_{2}$ NPs of 100,200 , and $300 \mathrm{mg} / \mathrm{kg}$ spiked in soil have shown Cd accumulation in Glycine max by 1.9, 2.1, and 2.6 folds in the shoots and 2.5, 2.6, and 3.3 folds in roots, respectively. However, $1534.7 \mathrm{mg} / \mathrm{kg}$ per pot of Cd was reported to be the maximum accumulation (Singh and Lee, 2016). The inoculation of Acaulospora mellea considerably enabled the immobilization of heavy metals. The acceptable concentration of nZVI was $50 \mathrm{mg} / \mathrm{kg}$ to $1000 \mathrm{mg} / \mathrm{kg}$ (Cheng et al., 2021).

The concentration of nZVI at 100, 500, and $1000 \mathrm{of} \mathrm{mg} / \mathrm{kg}$ showed effective uptake of Cd in the Boehmeria nivea L. root, stem, and leaves by 16-50\%, 29-52\%, and 31-73\%, respectively (Gong et al., 2017). Arbuscular mycorrhizal (AM) fungi, A. mellea along with nZVI have shown uptake of $\mathrm{Cd}, \mathrm{Pb}$, and $\mathrm{Zn}$ from the acidic soil by Sorghum bicolor L. A table has been appended below that exhibits the role of NPs in the phytoremediation of heavy metals (Table 1 ).

\section{Organic pollutants}

Organic pollutants are a major threat to agricultural soil, food chain, ecosystem, and human health. They are majorly released from industrial operations and agricultural applications (Alharbi et al., 2018). Phenols, polycyclic aromatic hydrocarbons (PAHs), organochlorine insecticides, and polychlorinated biphenyls (PCBs) are all examples of cyclic organic compounds that are documented as persistent organic pollutants (Sushkova et al., 2016, 2018). Many of them are lipophilic, thereby they tend to get bioaccumulated and biomagnified in adipose tissues of several organisms in the food chains of aquatic and terrestrial ecosystems (Penell et al., 2014).

Hence, phytoremediation is always considered as a cost-effective and sustainable approach to remediate these organic pollutants (Kang et al., 2018). Application of NPs in phytoremediation of organic pollutants like trichloroethylene, endosulfan, and trinitrotoluene have been reported in the past (Pillai and Kottekottil, 2016). Fullerene NPs have been reported to enhance the uptake of trichloroethylene using Populus deltoides, 2 and $15 \mathrm{mg} / \mathrm{L}$ of fullerene NPs have enhanced the uptake by $26 \%$ and $82 \%$. Plantago major with the appropriate adsorbent (activated charcoal) and solubilizing agent, $\mathrm{SiO}_{2}$ as green synthesized $\mathrm{NPs}$ of $\mathrm{Fe}$ and Ag namely Ficus-FeNPs (F-Fe0) (size $2.46 \mathrm{~nm}-11.49 \mathrm{~nm}$ ), Ipomoea-Ag (Ip-Ag0 ) (size 6.27 to $21.23 \mathrm{~nm}$ ) and Brassica-AgNPs (Br-Ag0 ) (size 6.05 to $15.02 \mathrm{~nm}$ ) were able to remove 93.7\%, 91.30\%, and 92.92\%, respectively of chlorfenapyr (Romeh and Saber, 2020). Studies have also reported that pollutants like chlorpyrifos, molinate and, atrazine could be removed and broken by nanosized zerovalent iron.

Plants that absorb contaminants in their tissues to breakdown and detoxify from the environment are used in nanophytoremediation. Plants that are favored for phytoremediation purposes should have characteristics such as:

- Fast grower with higher biomass producer

- The highly branched and well-developed root system

- Potential to tolerate and accumulate pollutants

- Higher sink potential that allows hyperaccumulation

- Easy harvesting of plant's sink organs

- Genetic manipulation should be easier, and

- It should be non-consumable by humans 
Table 1. Role of engineered NPs in the phytoremediation of $\mathrm{Pb}$ and $\mathrm{Cd}$ from the soil

\begin{tabular}{|c|c|c|c|c|c|}
\hline Pollution & Applied NPs & Mode of action of NPs & Plant name & Remarks & Reference \\
\hline \multirow{4}{*}{$\mathrm{Pb}$} & nZVI & $\begin{array}{l}\text { Lower concentration of } \\
\text { nZVI promoted plant } \\
\text { growth }\end{array}$ & $\begin{array}{l}\text { Kochia } \\
\text { scoparia }\end{array}$ & $\begin{array}{l}100-500 \mathrm{mg} / \mathrm{kg} \text { of nZVI } \\
\text { enabled } 857.18 \mu \mathrm{g} \text { per pot of } \\
\mathrm{Pb} \text { accumulation in the plant }\end{array}$ & land and Tabrizi, 2020 \\
\hline & $\begin{array}{l}\text { Nanohydroxya } \\
\text { patite }\end{array}$ & $\begin{array}{l}\text { Promoted plant growth } \\
\text { through phosphate } \\
\text { mobilization in the soil }\end{array}$ & L. perenne & $\begin{array}{l}\text { With nano-hydroxyapatite the } \\
\text { concentration of } \mathrm{Pb} \text { in the root } \\
\text { was reduced by } 2.86-21.1 \% \text { and } \\
\text { in the shoots } 13.19-20.3 \% \\
\text { reduction of Pb was observed }\end{array}$ & Ding et al., 2017 \\
\hline & nZVI & $\begin{array}{l}\text { Lower concentration of } \\
\text { nZVI promoted plant } \\
\text { growth }\end{array}$ & L. perenne & $\begin{array}{l}\text { Accumulated maximum } \\
\text { concentrations of } \mathrm{Pb} \text { in the root } \\
\text { and shoot of the plants }\end{array}$ & Huang et al., 2018 \\
\hline & $\begin{array}{l}\text { Nanohydroxya } \\
\text { patite }\end{array}$ & $\begin{array}{l}\text { Reduced phytotoxicity, } \\
\text { and enhance plant } \\
\text { growth }\end{array}$ & L. perenne & $\begin{array}{l}\text { The } 21.97 \% \text { remediation } \\
\text { efficiency was observed within } 6 \\
\text { weeks }\end{array}$ & Jin et al., 2016 \\
\hline \multirow[t]{2}{*}{$\mathrm{Cd}$} & $\mathrm{TiO}_{2}$ & $\begin{array}{l}\text { Improved germination } \\
\text { and photosynthetic } \\
\text { capacity of the plant }\end{array}$ & Glycine $\max$ & $\begin{array}{l}\text { Concentration ( } 100 \text { to } 300 \\
\mathrm{mg} / \mathrm{kg} \text { ) dependent increase in } \\
\text { the uptake of Cd was observed } \\
(128.5 \mu \mathrm{g}-507.6 \mu \mathrm{g} \text { of Cd per } \\
\text { plant) }\end{array}$ & Singh and Lee, 2016 \\
\hline & nZVI & Promoted plant growth & $\begin{array}{l}\text { Boehmeria } \\
\text { nivea }\end{array}$ & $\begin{array}{l}\text { Increase in the accumulation of } \\
\text { Cd in the leaves by } 31-73 \% \text {, } \\
\text { stems by } 29-52 \% \text {, and roots by } \\
16-50 \% \text { were recorded }\end{array}$ & Gong et al., 2017 \\
\hline $\mathrm{Pb}, \mathrm{Cd}$ & nZVI & Promoted plant growth & $\begin{array}{l}\text { Sorghum } \\
\text { bicolor }\end{array}$ & $\begin{array}{l}\text { Enhanced uptake of } \mathrm{Pb} \text { and } \mathrm{Cd} \text { of } \\
\text { the concentration } 50 \mathrm{mg} / \mathrm{kg} \text { to } \\
1000 \mathrm{mg} / \mathrm{kg}\end{array}$ & Cheng et al., 2021 \\
\hline $\mathrm{Pb}, \mathrm{As}$ & $\begin{array}{l}\text { CNT with } \\
\text { biochar }\end{array}$ & $\begin{array}{l}\text { Reduced seed } \\
\text { germination; however, } \\
\text { toxicity was modulated } \\
\text { by biochar }\end{array}$ & $\begin{array}{l}\text { Brassica } \\
\text { rapa }\end{array}$ & $\begin{array}{l}\mathrm{Pb} \text { was reduced by } 1.2-3.8 \text {-folds } \\
\text { and significantly reduced As } \\
\text { accumulation in the soil }\end{array}$ & Awad et al., 2019 \\
\hline $\begin{array}{l}\text { As, Cd, } \\
\mathrm{Pb}, \mathrm{Zn}\end{array}$ & nZVI & Stabilized HMs & $\begin{array}{l}\text { Helianthus } \\
\text { annuus, } \\
\text { L. perenne }\end{array}$ & $\begin{array}{l}\text { Reduced up to } 60 \% \text { uptake of As, } \\
\mathrm{Cd}, \mathrm{Pb} \text {, and } \mathrm{Zn} \text { in roots and shoots } \\
\text { compared to the control plants }\end{array}$ & Vítková et al., 2018 \\
\hline $\mathrm{Cd}, \mathrm{Pb}$ & Nano-silica & $\begin{array}{l}\text { Improved the } \\
\text { availability of } \mathrm{Pb} \text { and } \\
\mathrm{Cd} \text { to the plants, and } \\
\text { also promoted the } \\
\text { growth of the plant }\end{array}$ & $\begin{array}{l}\text { Secale } \\
\text { montanum }\end{array}$ & $\begin{array}{l}\text { Accumulation of Pb in } \quad \text { Moam } \\
\text { the roots was achieved up to } \\
533.6 \mathrm{mg} / \mathrm{kg} \mathrm{DW} \text { and Cd up to } \\
208.6 \mathrm{mg} / \mathrm{kg} \mathrm{DW} \text {. }\end{array}$ & neri and Khalaki, 2019 \\
\hline
\end{tabular}

\section{Microbial nanoremediation}

Microbes-mediated nanoremediation, a novel and efficient approach, involved the cellular enzymes secreted by microorganisms that successfully degraded and cleaned up the broad variety of organic pollutants in the contaminated ecosystem (Sangwan and Dukare, 2018; Torimiro et al., 2021). Numerous environmental conditions limit and influence the efficiency with which pollutants are degraded by microbes in contaminated soils. Within a microbial association, the biological response to environmental pollutants is differed, and the presence of co-contaminants may bring out changeable reactions to the bioremediation process (Sangwan and Dukare, 2018; Rajput et al., 2021c; Shende et al., 2021). Despite this, NBR offers a proficient and lucrative approach for contaminated soil and waste or groundwater treatment.

Microbes-mediated nanoremediation of xenobiotics is a fundamental environment-friendly approach to eradicate persistent toxic compounds gathered in the surroundings. The capacity of microbes to metabolize, transform, as well as degrade, xenobiotic compounds has been documented as a competent approach to remove dangerous and toxic wastes (Agarry and Solomon, 2008). Microorganisms are preferably appropriate to remove pollutants due to the enzyme system present that allocates them to utilize ecologically noxious pollutants as their energy and food source. The progressions in bioremediation science have been accredited to the individual as well as interdisciplinary contribution afforded by scientific areas of analytical chemistry, microbiology, biochemistry, molecular biology, environmental engineering, and very recently, nanobiotechnology (Hu et al., 2014; Sangwan and Dukare, 2018; Singh et al., 2020). The process of bioremediation includes mineralization and detoxification, in which the transformation of waste into inorganic compounds, like water, methane, and carbon dioxide has been carried out (Liu et al., 2018a; 
Vázquez-Núñez et al., 2020; Paterlini et al., 2021). Microbes can alter almost all organic materials, with catalytic mechanisms and wider diversity (Paul et al., 2005). They can function still in anaerobic plus extreme environmental conditions, which constructs them a smart candidate for the process of bioremediation.

Additionally, microorganisms play a significant function in biogeochemical cycles as well as the ecosystems' sustainability. The conversion of xenobiotic contaminants by microbes may occur either in an anoxygenic or oxygenic environment. Nevertheless, molecular oxygen contributes to aliphatic as well as aromatic xenobiotic compounds (Cao et al., 2009; Sinha et al., 2009). Amid the different microorganisms, bacteria have been established as the most competent and prevailing in the natural bioremediation processes. In both the conditions, i.e., aerobic as well as anaerobic, bacteria have developed an approach for acquiring energy from nearly every compound by electron acceptors like ferric ions, sulfate, nitrate, etc. Several genera of bacteria, e.g., Alcaligenes, Acinetobacter, Bacillus, Escherichia, Gordonia, Moraxella, Micrococcus, Pseudomonas, Pandoraea, Rhodococcus, Streptomyces, and Sphingobium either independently or in amalgamation are implicated in oxygenic breakdown. In contrast, bacterial genera concerned with the anaerobic degradation of xenobiotics include Azoarcus, Clostridium, Desulfotomaculum, Desulfovibrio, Geobacter, Methanococcus, Methanosaeta, Pelotomaculum, Syntrophobacter, Syntrophus, and Thauera (Jindrova et al., 2002; Van Hamme Jonathan et al., 2003; Kulkarni and Chaudhari, 2007; Weelink et al., 2010; Sangwan and Dukare, 2018)

The remediation of extremely persistent and xenobiotic water and soil contaminants, such as hydrocarbons, heavy metals, dye in textile (acid dyes, cationic dyes, azo dyes), pharmaceutical constituents (antibiotics and antiseptics), and other such contaminants are critical for wastewater and soil treatment and its future application. These contaminants increase pollution and pessimistically affect the environment (Koul et al., 2021; Sushkova et al., 2016).

Since NPs have a larger surface area and are smaller, they can act as catalysts or adsorb contaminants above a larger surface area. Numerous reports documented the catalytic properties of various NPs together with the biological components have been assessed to reduce harmful pollutants (Zhao et al., 1998; Kharissova et al., 2013). Many microorganisms have been utilized to hone NPs exploitation for the NBR process as several researchers reported encouraging outputs in the application of microbe-mediated NPs in the process of remediation.

An extensive recognition of microbes for this scientific approach was recognized owing to their exceptional chemical, physical, biological, as well as optical properties like super-hydrophobic and filtering nature, sensitive affinity membranes, modifiable functionality, as well as a higher surface-to-volume ratio (Sarwar et al., 2017; Wang et al., 2015; Sangwan and Dukare, 2018).

A detailed description of microbes-mediated nanoremediation has been given in the forthcoming sections.

\section{Hydrocarbons}

Many researchers have been reported that the microbes-mediated nanoremediation of persistent organic pollutants; i.e., hydrocarbon. It was reported the electrostatic interaction of magnetic NPs functionalized by Rhodococcus erythropolis harnessing system that substantively bio-desulfurize hydrocarbon component dibenzothiopene (DBT) by 56\%. Thus, validating the advantage of magnetic NPs functionalized by $R$. erythropolis above the solitary exploitation of every component for bioremediation (Ansari et al., 2009). The efficient synergistic effect of the nZVI with Sphingomonas sp. as an effectual twosome towards the debromination and gradual polybrominated diphenyl ethers (PBDEs) degradation in aqueous solution (Kim et al., 2012). Alternatively, the feasibility of the combined employ of bimetallic (Pd/nFe) NPs and Sphingomonas wittichii for the NBR 2,3,7,8-tetrachlorodibenzo-p-dioxin hydrocarbon was also recognized (Bokare et al., 2012). The active dechlorination facilitated by integrated hybrid (nano-bioredox) resulted to form dibenzo-p-dioxin.

A study has revealed the applications of Sphingomonas sp. as a bio-functionalized tool for carboxymethyl cellulose (CMC) stabilized bimetallic (Pd/Fe) NPs (Singh et al., 2013). The nano-composite was found to be triumphant for the deprivation of gamma-hexachlorocyclohexane $(\gamma-\mathrm{HCH})$, generally identified as lindane and the main component in cosmetics (Singh et al., 2013). The study was performed to remove Aroclor 1248- a congener of PCBs, where the noteworthy de-chlorination, as well as conversion of the contaminant, was observed by the treatment of bimetallic $(\mathrm{Pd} / \mathrm{Fe})$ NPs under anoxic surrounding resulted in the formation of biphenyls (Le et al., 2015). Progressive bioremediation of the resulting biphenyls further catalytically decreased the persistent Aroclor 1248 from $33.8 \times 10^{-5} \mu \mathrm{g} / \mathrm{g}$ to $9.5 \times 10^{-5} \mu \mathrm{g} / \mathrm{g}$ with Burkholderia 
xenovorans (Le et al., 2015). The silica NPs biofunctionalized with lipid bilayers of Pseudomonas aeruginosa was investigated to clean up PAH (benzo[a]pyrene) (Wang et al., 2015). The 1,2-dimyristoylsn-glycero-3phosphocholine, lipid molecule playing a dynamic role, to improve the sequestration or adsorption of the PAHs, when conjugated by silica NPs. The biofunctionalized graphene oxide NPs with laccase enzyme developed by Trametes versicolor were studied for their potential as well as combine enhance for the biodegradation of PAH (anthracene) (Patil et al., 2016). The amalgamation of laccase enzyme from fungi as conjugant was reported to have the enhanced ability of degradation than their single application and also extended their stability. The polymer (polyallylamine hydrochloride)-layered magnetic NPs functionalized by Alcanivorax borkumensis established an opportunity for vigorous hydrocarbon degradation (Konnova et al., 2016). Exceptional features like forming the neutral lipid inclusions in biofilms of $A$. borkumensis, the biosurfactant micelle ascertain the opportunity of hydrocarbon decomposition.

Bacillus licheniformis-mediated nanoremediation process was evaluated bio-functionalization of $\mathrm{Zn}_{5} \mathrm{OH}_{8} \mathrm{Cl}_{2}$ modified $\mathrm{Fe}_{2} \mathrm{O}_{3}$ NPs with $B$. licheniformis to break crude oil into naturally degradable compounds. Additionally, demonstrate some prospects on the promising improvement of microbial bio-surfactants for efficient NBR of widespread oil pollution (El-Sheshtawy and Ahmed, 2017). The synergistic effect concerning iron oxide NPs and Alkaligenes faecalis improved the crude oil biodegradation in the contaminated environment (Oyewole et al., 2019). The authors observed that assessing variable deliberations of $A$. faecalis with iron oxide NPs, at 200 mg efficiently cleans up crude oil pollution.

\section{Heavy metals}

Microbes-mediated nanoremediation of heavy metals corroborates the potential of microorganisms in cleaning up the environment. NPs' effectiveness in bioremediation was accomplished during the in-situ fabrication of palladium (Pd) NPs from Pd (II) ions intervened by Clostridium pasteurianum acquired from sandy aquifer matter. The biosynthesized Pd NPs evidenced positive remediation in the alteration of hexavalent chromium; i.e., $\mathrm{Cr}$ (VI) into insoluble $\mathrm{Cr}$ (III) and, therefore, leading to the production of hydrogen gas (Chidambaram et al., 2010). In this study, the removal rate of $\mathrm{Cr}$ (VI) was considerably improved, reaching $7.2 \mathrm{~g}$, indicating the importance of nano-catalysts over traditional in situ bio-simulation techniques. A comparable strategy accomplished was channeled towards reduction of $\mathrm{Cr}$ (VI) by sodium alginate, polyvinyl alcohol (PVA), as well as a matrix of carbon nanotubes (CNTS) immobilized upon Pseudomonas aeruginosa cells (Pang et al., 2011). The biogenic Cr (VI) reduction to soluble Cr (III) was shown in wastewater by the immobilized bacterial cells (Nancharaiah et al., 2010).

In the NBR process, algae also have revealed their significance. Iron NPs fabrication by Chlorococcum $s p$. demonstrated a noticeable elimination of Cr (VI) to Cr (III) about 92\% of $4 \mathrm{mg} / \mathrm{L}$ (Subramaniyam et al., 2015). Iron NPs synthesized from algae was mediated with the biomolecules from algal cell illustrated more excellent stability, high reactivity, and proficient toxic pollutants reduction in the environment. On the other hand, the biogenic role of Lysinibacillus sphaericus in the production of magnetic oxide NPs intended to remove $\mathrm{Cr}$ (VI) contamination from the surroundings (Kumar et al., 2019). The authors reported the employ of exopolysaccharides (EPS) matrix of biofilm derived from L. sphaericus as a superior reducing, capping, and stabilizing agent, acquiring several binding sites for different metal ions. Magnetic oxide NPs functionalized with EPS illustrated the improved potential to adsorb $\mathrm{Cr}$ (VI). In another study, it was reported the integration of Chlorella vulgaris in ultrafine bi-metallic i.e., $\mathrm{TiO}_{2} / \mathrm{Ag}$ chitosan nanofiber mats, as a functionalized agent, elucidated the significance of algae in the photo-removal strategy of $\mathrm{Cr}$ (VI) under UV light irradiation (Wang et al., 2017a). The discharge of organic substances such as chlorophylls, carboxylic acids, etc., through $C$. vulgaris, was documented to have an improved photocatalytic reduction of $\mathrm{Cr}$ (VI) on the $\mathrm{TiO}_{2} / \mathrm{Ag}$ chitosan nanofiber mats, confirming the synergistic way of hybrid NPs by algae and $\mathrm{TiO}_{2} / \mathrm{Ag}$.

The fabrication of lead sulfide i.e., PbS NPs from Rhodosporidium diobovatum demonstrating the prospect of a straightforward breaking down of $\mathrm{Pb}(\mathrm{II})$ ions into less toxic and helpful forms by fungi (Seshadri et al., 2011). The triumphant elimination of Cd in Cd-polluted water illustrated the competence of Pseudomonas aeruginosa improved Cd bioreduction which in turn hasten the cadmium sulfide (CdS) NPs biosynthesis (Raj et al., 2016). Likewise, the removal and bioremediation of Cd from Cd-polluted soils also evaluated (Liu et al., 2018b). The authors demonstrated that the co-treatment of Bacillus subtilis and nano-hydroxyapetite (NHAP) efficiently eliminated the Cd contamination, encouraging the propagation of microbial community of rhizosphere along with the diversity of bacteria in the remediated soil (Liu et al., 2018b).

The evaluation of somewhat variable biofunctionalized approach including polyvinylpyrrolidone (PVP)coated iron oxide NPs intermingled with Halomonas sp. isolated from the oil-contaminated soil, has been reported (Alabresm et al., 2018). Selenium NPs were found efficient in NBR of mercury polluted soil; those 
NPs were formed by the occurrence of Citrobacter freudii (Wang et al., 2017c). The alteration of elemental form of $(\mathrm{Hg} 0)$ to the insoluble form mercuric seleniide (HgSe) with biogenic selenium NPs evaluated under aerobic as well as anaerobic conditions accounted for a bioremediation value 39.1-48.6\% and 45.8-57.1\%, respectively. The nickel compound was removed in the effluent by introducing Microbacterium sp. resulting in the production and recovery of nickel oxide NPs (Sathyavathi et al., 2014). In another study, the potential of Hypocrea lixii was discovered to reduce noxious metals, specifically nickel, in contaminants and devising the nickel oxide NPs biosynthesis from the waste for further applications (Salvadori et al., 2015).

Recently, it was demonstrated that the silver (Ag) NPs synthesized through greener way assisted by Bacillus cereus was supported with alumina, found efficient in NBR of pharmaceutical effluents restraining heavy metals, mostly chromium ( $\mathrm{Cr}$ ) and lead (Pb) (Kumari and Tripathi, 2020). The bacterial cell-mediated nanoadsorbent method certified to remove about 98.13\% (Cr) and 98.76\% (Pb) that were discharged from pharmaceutical industries as waste effluents. The possibility of nanobioremediation of cadmium (Cd) and lead $(\mathrm{Pb})$ in the soil by the mutual exploitation of Escherichia coli along with metal NPs towards the elimination of these heavy metals (Zhu et al., 2020).

\section{Pharmaceutical ingredients}

The recurrent emancipation of pharmaceutical ingredients (antiseptics and antibiotics) in wastewater is considered a serious concern. These mainly originate from domestic and industrial effluents, which have polluted not only the environment but also enhanced the appearance of antibiotic-resistant microbes in wastewater (Adesoji et al., 2020). Nevertheless, the prospect of eliminating these pharmaceutical ingredients by the NBR strategy was evaluated as per the many research studies. The biosynthesis of both $\mathrm{Au}$ and Ag NPs using Turbinaria conoides, an alga which was found useful as an antimicrofouling agent (Vijayan et al., 2014). Hydrogen peroxide, a common pharmaceutical ingredient, yet a pollutant of the environment, was proficiently removed from waste effluents from industries by the electrocatalytic reduction of the compound aided with Pd NPs synthesized Sargassum bovinum (Momeni and Nabipour, 2015).

Micro-accumulation of triclosan, which has been found to be linked with cancer, has frequently been used as an antibacterial and antiseptic agent. Nevertheless, the significance of fungi (Trametes versicolor) as an essential biofunctionalized agent for bimetallic ( $\mathrm{Pd} / \mathrm{Fe})$ NPs to remove triclosan in liquid effluents was established (Bokare et al., 2010). In this work, T. versicolor was observed to secrete laccase enzyme that was found to play a vital role in the two-step redox strategy, which involved the anaerobic dechlorination as well as sequential oxidation of 2-phenoxy phenol. Similarly, (Adikesavan and Nilanjana, 2016) described the magnesium oxide (MgO) NPs biofunctionalization by yeast (Candida sp.). The myco-nano approach was found to have hastened the process of Cefdinir degradation and treatment in an aqueous environment. A group of bacteria conquered by Bacillus and Pseudomonas spp. accountable for the biosynthesis of manganese oxide ( $\mathrm{MnO}$ ) NPs was found to efficiently eradicate 1,2,4-triazole from wastewater (Wu et al., 2017). This study established the prospective of biogenic manganese oxide NPs to remove a variety of recalcitrant pollutants from bio-treated chemical industrial wastewater.

The efficiency of Pt and Pd NPs biosynthesized from Desulfovibrio vulgaris to remove effluents containing pharmaceutical compounds was reported. The numerous chemical compounds contribute greatly to the pharmaceutical industry. Likewise, 1,2,4-triazole used in different clinical applications because of a large number of compounds of the ring system. Besides, 1,2,4-triazole is also applied in the production of pesticides that often contributes to groundwater pollution during leaching (Martins et al., 2017). Similarly, picric acid (2,4,6-trinitrophenol (TNP), is a valuable constituent in the production of antiseptic, posturing hazard to the environment as a pollutant in an aqueous solution. The study established the progressive application of Pseudomonas aeruginosa mediated $\mathrm{Fe}_{3} \mathrm{O}_{4}$ NPs as a portion of multiwalled carbon nanotubes (MWCNT) to produce nanocomposite moderately employed for NBR of picric acid (Yousefi et al., 2020).

\section{Dyes in textile}

Dyes have been widely recognized as an essential component in a multitude of sectors, including cosmetics and textiles. Nevertheless, it is disposed-off mainly as liquid waste matter into the surroundings, which is poisonous to living beings (Asaduzzaman et al., 2016). A study ascertained the coalesce effect of biofunctionalized Ag NPs by Chromobacterium violaceum as a biosorption strategy to remediate washing water employed to process cotton fabrics (Durán et al., 2010; Duran et al., 2017). This process demonstrated the successful removal of organic compounds as well as dyes used in the production of fabrics. This treatment further illustrated its effectiveness for eliminating used Ag NPs and the revival of bacteria, posing lesser harm to the environment. The application of Ag NPs synthesized from Bacillus pumilis have been used 
to remediate the Congo red dye from wastewater, which was applied on cotton fabrics (Modi et al., 2015). The goal was to develop and implement an efficient method for removing Congo red dye because it is less resistant to light and washing. The highest revival of Ag NPs leached in the effluents to evade harm to the environment.

In another study, it was observed that Ag NPs competently decolorize the organic dyes during the catalytic activity and confirmed that NPs might be employed as catalysts in industries to degrade organic dyes with higher competence (Sharma et al., 2015). It has been reported that Ag and Au NPs demonstrated good catalytic activity in the removal of organic dyes. These NPs reduced the time requisite for eliminating dye while also competently improved the rate of reaction (Suvith and Philip, 2014). The Au NPs could also be employed as adsorbents for organic dyes. As Au NPs, comprising surface proteins produced from fungus Cladosporium oxysporum AJP03, efficiently enhanced the rhodamine-B organic dye adsorption (Bhargava et al., 2016). The roles of different NPs and nanocomposites such as $\mathrm{TiO}_{2} \mathrm{NPs}$, FeNPs, magnetic NPs, bimetallic NPs, nanotubes, nanoclays, and nanosponges in the NBR of soil are also revealed (Koul and Taak, 2018). The authors accentuated that the synthesis of NPs by green methods might be an efficient approach for treating water and soil pollution. The efficient catalysis of Congo red dye by Ag NPs synthesized from green alga Caulerpa serrulate was reported (Aboelfetoh et al., 2017).

Even though methyl orange dye is infrequently employed in textile because of its susceptibility to acids, they still find expediency as a dye for wool fabrics, a type of contaminant in wastewater. Mechanism of NBR evaluated the consortium of Cellulosimicrobium sp., Micrococcus lylae, and Micrococcus aloeverae to produce $\mathrm{TiO}_{2}$ NPs (Fulekar et al., 2018). The active degradation of methyl orange dye was achieved in a reactor by the influence of UV light. These rhizospheric root-associated microorganisms demonstrated the opportunity and efficiency of normal sources for the biosynthesis of NPs and around 99\% of methyl orange dye photocatalytic degradation, a signal for the significance of photocatalytic process for a safe environmental and passable nanobioremediation system. A comparable discovery was recognized for algae Hypnea musciformis [wulfen] J.V Lamouroux-mediated synthesis of Ag NPs and their dynamic efficacy in humiliating methyl orange dye solution under visible light (Ganapathy Selvam and Sivakumar, 2015). An effort on the Azo dyes bio-reduction, which are imperative synthetic colorants are generally used in textile, paper manufacturing, printing, etc. was conceded out by Pd NPs fabricated from Klebsiella oxytoca (Wang et al., 2018). The synthetic organic colorants were effectively bio-reduced with recovery from the effluent liquids. The biosynthesized polysulfone nanofibrous web and Chlamydomonas reinhardtii were originated a synergistic effect that removes reactive dyes from wastewater (San Keskin et al., 2015).

The Ag NPs synthesized from microalgae Caulerpa racemosa and Chlorella pyrenoidosa were reported for the photo-catalytic degradation of methylene blue and the treatment of liquid effluent containing hazardous dye produced significant results i.e., dropping the level of the contaminants under controlled experimental conditions (Aziz et al., 2015; Edison et al., 2016). In recent work, the descriptive information on various approaches for the NPs synthesis using microbial cells; their applications in agriculture, bioremediation, diagnostics, and medicine; and their prospects are provided (Koul et al., 2021).

\section{Other toxic chemicals}

Besides these major groups of pollutants, there are found some other toxic chemicals in the environment. The biogenic synthesis of manganese oxide NPs by Pseudomonas putida documented the bacteria potential for sufficient removal of organic micropollutants (Furgal et al., 2015). Bisphenol A (BPA), generally known as an essential chemical substance exploited in the industries for developing resins and plastics, requisite for storage of food and beverages, has become an aggravation to the ecology. The elimination of bisphenol A by a route focused on applying MnO NPs biosynthesized from algae (Desmodesmus sp.) (Wang et al., 2017b). Commercially produced nitro compounds for solvents or chemical intermediates create a relatively extensive volume in effluents from industries (Torimiro et al., 2021).

The application of Chlorella vulgaris on nitrate removal from liquid effluents, in which algae played a dual role in biogenic production of Pd NPs and its immobilization on nanofibre mats prepared by an electrospun method that improves the catalytic activity of the complex to remove nitrate from liquid effluents was demonstrated (Eroglu et al., 2013). NBR mechanism evaluated in Sargassum tenerrimum and Tubinaria conoides for the biological production of Au NPs applied to reduce the nitro compounds in wastewater (Ramakrishna et al., 2016). 


\section{Environmental concerns and future perspective}

Environmental contamination is a serious issue that humanity is currently struggling with (Litvinov et al., 2017; Sushkova et al., 2017; Rajput et al., 2017b,2018). Numbers of techniques are being used and some others are under trial for the remediation of contaminants of the environment (Song et al., 2019; Baig et al., 2021; Kumar et al., 2021; Kumari et al., 2021; Paterlini et al., 2021). There are several examples which are come under the category of contaminants, such as pesticides, herbicides, sewage and organic compounds, toxic gases, fertilizers, trace metals etc. (Vaseashta et al., 2007; Khan and Pathak, 2020). Therefore, to deal with these challenges, the engagement of NPs in the expansion of emerging green remediation technologies has been the subject of recent investigations (Tratnyek and Johnson, 2006). NBR is a unique technology employed in transforming the adverse effects of pollutants into safer molecules through NPs.

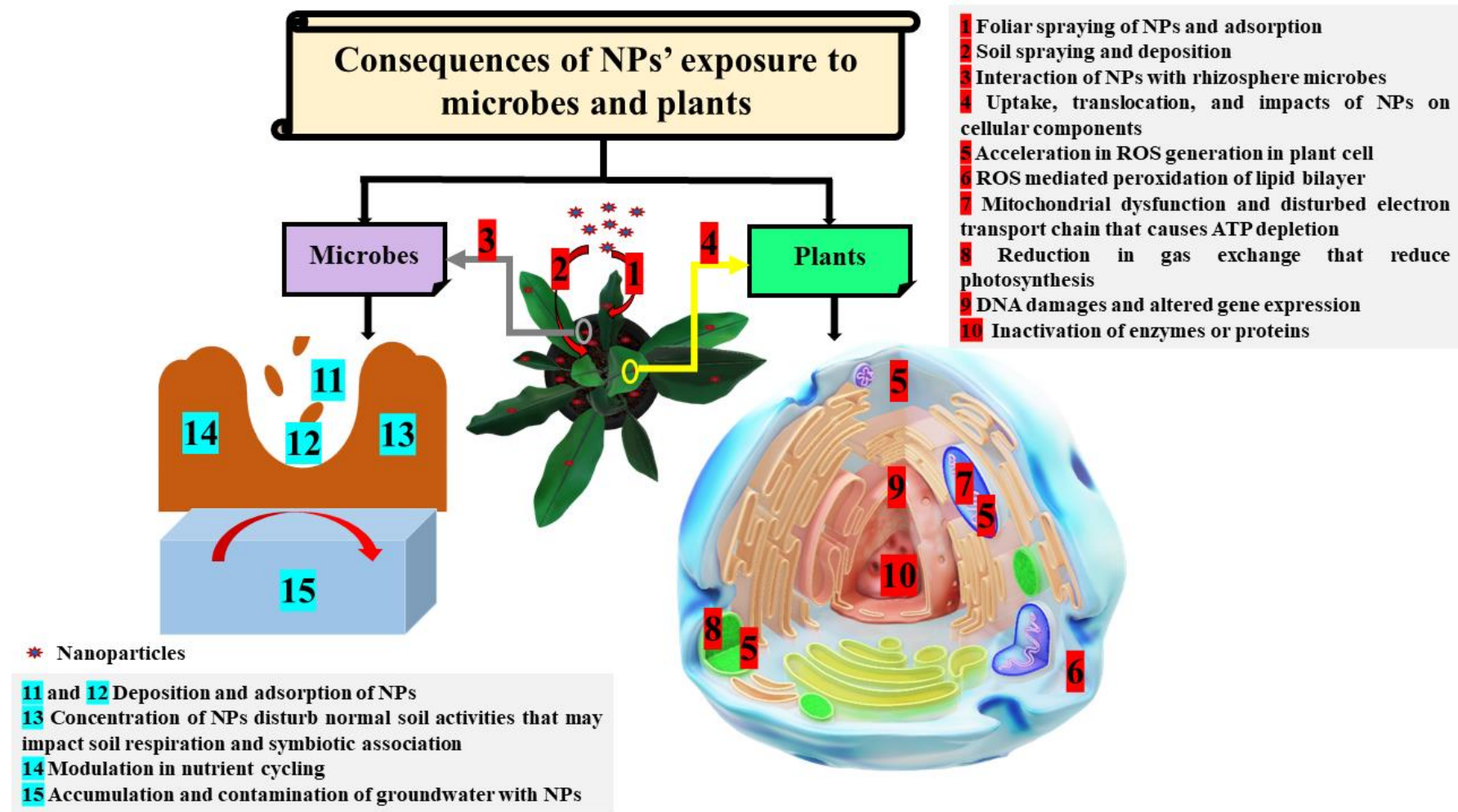

Figure 2. The exposure of NPs and associated impacts on microbes and plants

However, nanotechnology has gained very much importance in recent years because of its extraordinary properties. It has been accounted to play a major function in tackling diverse efficient and inventive resolutions to several ecological confront (Yan et al., 2013; Reddy et al., 2014). But pioneering thoughts for progress are similar a twice impacts. Every unique approach has been connected to pros and cons. It depends on researchers how they tackle and apply the new approach. In the turf of NBR, the negative aspects related to NPs are very significant and crucial which cannot be disregarded (Jiang et al., 2018; Rajput et al., 2021b).

Besides their positive effects, some negative aspects of NPs are also being seen in the environment. It is documented that NPs do not supply any profit in the situation of bioaugmentation, since they stop the microbial inhabitants in contaminated surroundings (Nzila et al., 2016; Amoatey and Baawain, 2019). The appliance of NPs for ecological action intentionally injects NPs into the soil or water body. This has finally involved rising anxiety from all stakeholders. The compensation of NPs such as their minute size, elevated activity, and immense capacity, could develop into a possible deadly feature by inducing unfavorable cellular toxic and damaging properties, abnormal in small-sized counterparts (Figure 2).

In stiff water and seawater, NPs tend to aggregate and are greatly influenced by the type of natural material or other natural colloids present in freshwater. The situation of dispersal will change the ecotoxicity, but several abiotic factors that influence this, such as $\mathrm{pH}$, salinity, and the attendance of organic matters stay to be methodically investigated (Handy et al., 2008). It was demonstrated that the hindering effect of the nZVI in soils happens when the NPs begin to be putting on the facade of the soil particles, accumulating in such a method that they attract additional constituent parts in suspension, jamming the way of fluids (Reddy et al., 2014). Since the strainer result occurs as the concluding phase of deposition, which ends up providing a 
"clogging" of the soil hole, not allowing for the channel of the element. It has been confirmed that carbon nanotubes (CNT) abridged the biodegradation pace by hindering bacterial expansion and microbial action (Zhang et al., 2015).

Nanosorbent have a significant impact in explaining ecological subjects like the filtration of water that established immense interests because of their unique physicochemical properties. However, the use of nanosorbent material in water bodies can also have certain negative consequences (Yaqoob et al., 2020). Major drawbacks are the probable negativity of the remaining NPs in the water and their large size which causes that few probable functioning is not used (Zhu et al., 2019). The exercise of silver NPs in many products direct them to their discharge to the water body and befall a source of suspended silver and thus produce negative impacts on marine organisms (Navarro et al., 2008).

Several microbes are present in the water body; therefore, it is a very natural process for NPs to encounter microbes after they are released into the water body. When nZVI is in straight connection with bacterial cells, it results in oxidative stress and membrane demolition (Figure 2). The current study represents the thrashing of intracellular components and the disturbance of communication between the outside and inside environment of the bacteria (Lv et al., 2017).

Carbon nanotubes change the oxidation nature of enzymes in water molecules, which causes adverse impacts on microbes (Chen et al., 2016). Graphene oxide enhances the active oxygen application, but it does not harm cells. However, a higher concentration of silver NPs are used, the enzymatic action was retarded, but the genes for resistance were augmented (Li et al., 2019; Kolesnikov et al., 2021). The application of silver NPs and zinc oxide NPs on the activity of bacterial is reported to depend on the dimension of particles, and the microorganism concentration (Mboyi et al., 2017). Treatment of zinc oxide NPs to anaerobic fermentation, zinc ions are engrossed in the mud, however, bacterial quantity, cell activity, enzymatic activity, and zinc ion concentration significantly decreased (Figure 2).

Generally, the negative impacts of NPs on microbial activity largely engage membrane devastation and oxidative stress (Rajput et al., 2017a; Chen et al., 2019). Conclusively, microorganisms and planktons are highly vulnerable to the toxicity of NPs. Furthermore, these water-loving organisms are pretentious by the adverse effects of NPs, and occasionally it is quite hard to recover due to those NPs not simply root of cell injury, but also harm genes and influence reproduction.

\section{Challenges associated with nanobioremediation}

- Nanophytoremediation studies are yet to be adopted widely and need to explore rigorously.

- Most studies using nanophytoremediation approaches are microcosm therefore in-situ and realistic studies in future research could bring a new direction in this scope

- Time series and long-term research using NPs are also necessary, that can enable us to observe the actual effects of NPs in phytoremediation progression and also their effect on soil characteristics, microbiome, and nutrients

- NPs may get aggregate, dissolved, undergo dissociation in different soil $\mathrm{pH}$, or it can also undergo photodegradation. These processes certainly affect their mobility. Application of doping, composite, or polymeric structure for nanophytoremediation must be explored in this regard.

- Assessment of effects and safety of NPs application in agriculture or polluted soil should be mandatory. Sustainable nanophytoremediation largely relies on climatological conditions hence our exploration should also include the identification of a naturally stable NPs

\section{Conclusion}

The advent in nanobiotechnology as a research field brings up possibilities for developing nanoremediation methods for the restoration of contaminated soils. Several investigations' experimental findings revealed the potential of nanobioremediation for the removal of various inorganic and organic pollutants from terrestrial ecosystems. Also, these techniques could be applied to decontaminating air, or water, in cost-effective ways; however, significant environmental concern regarding the application of NPs should be in the regulatory framework, and eco-friendly. Thus, the understanding of NPs interaction with plants, microbes, pollutants, and human health is of utmost importance as these effects might be negative or positive. Thus, nanobioremediation will undoubtedly be a promising tool for achieving environmental sustainability once these research gaps regarding its environmental concerns will have been revealed.

\section{Acknowledgements}

The study was supported by a grant from the Russian Science Foundation 19-74-10046. 


\section{References}

Aboelfetoh, E.F., El-Shenody, R.A., Ghobara, M.M., 2017. Eco-friendly synthesis of silver nanoparticles using green algae (Caulerpa serrulata): reaction optimization, catalytic and antibacterial activities. Environmental Monitoring and Assessment 189: 349.

Adesoji, T.O., Egyir, B., Shittu, A.O., 2020. Antibiotic-resistant staphylococci from the wastewater treatment plant and grey-water samples in Obafemi Awolowo University, Ile-Ife, Nigeria. Journal of Water \& Health 18(6): 890-898.

Adikesavan, S., Nilanjana, D., 2016. Degradation of cefdinir by Candida Sp. SMN04 and Mg0 nanoparticles-An integrated (Nano-Bio) approach. Environmental Progress \& Sustainable Energy 35(3): 706-714.

Agarry, S.E., Solomon, B.O., 2008. Kinetics of batch microbial degradation of phenols by indigenous Pseudomonas fluorescence. International Journal of Environmental Science \& Technology 5: 223-232.

Alabresm, A., Chen, Y.P., Decho, A.W., Lead, J., 2018. A novel method for the synergistic remediation of oil-water mixtures using nanoparticles and oil-degrading bacteria. Science of The Total Environment 630: 1292-1297.

Alharbi, O.M.L., Khattab, R.A., Ali, I., 2018. Health and environmental effects of persistent organic pollutants. Journal of Molecular Liquids 263: 442-453.

Ali, H., Khan, E., Sajad, M.A., 2013. Phytoremediation of heavy metals-concepts and applications. Chemosphere 91(7): 869-881.

Amoatey, P., Baawain, M.S., 2019. Effects of pollution on freshwater aquatic organisms. Water Environment Research 91(10): 1272-1287.

Ansari, F., Grigoriev, P., Libor, S., Tothill, I.E., Ramsden, J.J., 2009. DBT degradation enhancement by decorating Rhodococcus erythropolis IGST8 with magnetic $\mathrm{Fe}_{3} \mathrm{O}_{4}$ nanoparticles. Biotechnology and Bioengineering 102(5): 1505-1512.

Asaduzzaman, M.M., Hossain, F., Li, X., Quan, H., 2016. A study on the effects of pre-treatment in dyeing properties of cotton fabric and impact on the environment. Journal of Textile Science \& Engineering 6(5): 1000274.

Awad, Y.M., Vithanage, M., Niazi, N.K., Rizwan, M., Rinklebe, J., Yang, J.E., Ok, Y.S., Lee, S.S., 2019. Potential toxicity of trace elements and nanomaterials to Chinese cabbage in arsenic- and lead-contaminated soil amended with biochars. Environmental Geochemistry and Health 41: 1777-1791.

Aziz, N., Faraz, M., Pandey, R., Shakir, M., Fatma, T., Varma, A., Barman, I., Prasad, R., 2015. Facile algae-derived route to biogenic silver nanoparticles: Synthesis, antibacterial, and photocatalytic properties. Langmuir 31: 11605-11612.

Baig, M.M., Zulfiqar, S., Yousuf, M.A., Shakir, I., Aboud, M.F.A., Warsi, M.F., 2021. Dy $\mathrm{MnFe}_{2-\mathrm{x}} \mathrm{O}_{4}$ nanoparticles decorated over mesoporous silica for environmental remediation applications. Journal of Hazardous Materials 402: 123526.

Bayda, S., Adeel, M., Tuccinardi, T., Cordani, M., Rizzolio, F., 2019. he History of nanoscience and nanotechnology: from chemical-physical applications to nanomedicine. Molecules 25: 112.

Bhargava, A., Jain, N., Khan, M.A., Pareek, V., Dilip, R.V., Panwar, J., 2016. Utilizing metal tolerance potential of soil fungus for efficient synthesis of gold nanoparticles with superior catalytic activity for degradation of rhodamine B. Journal of Environmental Management 183: 22-32.

Bokare, V., Murugesan, K., Kim, J.H., Kim, E.J., Chang, Y.S., 2012. Integrated hybrid treatment for the remediation of 2,3,7,8-tetrachlorodibenzo-p-dioxin. Science of The Total Environment 435-436: 563-566.

Bokare, V., Murugesan, K., Kim, Y.M., Jeon, J.R., Kim, E.J., Chang, Y.S., 2010. Degradation of triclosan by an integrated nano-bio redox process. Bioresource Technology 101(16): 6354-6360.

Burachevskaya, M., Nevidomskaya, D., Tsitsuashvili, V., Rajput, V., Bren, D., 2020. Lead compounds in bottom sediments of the Seversky Donets floodplain. E3S Web of Conferences 169: 01004.

Cao, B., Nagarajan, K., Loh, K.C., 2009. Biodegradation of aromatic compounds: current status and opportunities for biomolecular approaches. Applied Microbiology and Biotechnology 85: 207-282.

Cecchin, I., Reddy, K.R., Thome, A., Tessaro, E.F., Schnaid, F., 2017. Nanobioremediation: Integration of nanoparticles and bioremediation for sustainable remediation of chlorinated organic contaminants in soils. International Biodeterioration \& Biodegradation 119: 419-428.

Chauhan, R., Yadav, H.O.S., Sehrawat, N., 2020. Nanobioremediation: A new and a versatile tool for sustainable environmental clean up-Overview. Journal of Materials and Environmental Sciences 11(4): 564-573.

Chen, M., Qin, X., Zeng, G., 2016. Single-walled carbon nanotube release affects the microbial enzyme-catalyzed oxidation processes of organic pollutants and lignin model compounds in nature. Chemosphere 163: 217-226.

Chen, M., Sun, Y., Liang, J., Zeng, G., Li, Z., Tang, L., Zhu, Y., Jiang, D., Song, B., 2019. Understanding the influence of carbon nanomaterials on microbial communities. Environment International 126: 690-698.

Cheng, P., Zhang, S., Wang, Q., Feng, X., Zhang, S., Sun, Y., Wang, F., 2021. Contribution of nano-zero-valent iron and arbuscular mycorrhizal fungi to phytoremediation of heavy metal-contaminated Soil. Nanomaterials 11(5): 1264.

Chidambaram, D., Hennebel, T., Taghavi, S., Mast, J., Boon, N., Verstraete, W., van der Lelie, D., Fitts, J.P., 2010. Concomitant microbial generation of palladium nanoparticles and hydrogen to immobilize chromate. Environmental Science \& Technology 44: 7635-7640.

Ding, L., Li, J., Liu, W., Zuo, Q., Liang, S.X., 2017. Influence of nano-hydroxyapatite on the metal bioavailability, plant metal accumulation and root exudates of ryegrass for phytoremediation in lead-polluted soil. International Journal of Environmental Research and Public Health 14(5): 532. 
Duran, N., Marcato, P.D., Alves, O.L., Da Silva, J.P.S., De Souza, G.I.H., Rodrigues, F.A., Esposito, E., 2010. Ecosystem protection by effluent bioremediation: silver nanoparticles impregnation in a textile fabrics process. Journal of Nanoparticle Research 12: 285-292.

Duran, N.M., Savassa, S.M., Lima, R.G., de Almeida, E., Linhares, F.S., van Gestel, C.A.M., Pereira de Carvalho, H.W., 2017. $\mathrm{X}$-ray spectroscopy uncovering the effects of cu based nanoparticle concentration and structure on phaseolus vulgaris germination and seedling development. Journal of Agricultural and Food Chemistry 65: 7874-7884.

Ebbs, S.D., Kochian, L.V., 1998. Phytoextraction of zinc by oat (Avena sativa), barley (Hordeum vulgare), and indian mustard (Brassica juncea). Environmental Science \& Technology 32: 802-806.

Edison, T.N.J.I., Atchudan, R., Kamal, C., Lee, Y.R., 2016. Caulerpa racemosa: a marine green alga for eco-friendly synthesis of silver nanoparticles and its catalytic degradation of methylene blue. Bioprocess and Biosystems Engineering 39: 1401-1408.

Ekta, P., Modi, N.R., 2018. A review of phytoremediation. Journal of Pharmacognosy and Phytochemistry 7(4): 14851489.

El-Sheshtawy, H.S., Ahmed, W., 2017. Bioremediation of crude oil by Bacillus licheniformis in the presence of different concentration nanoparticles and produced biosurfactant. International Journal of Environmental Science and Technology 14: 1603-1614.

Eroglu, E., Chen, X., Bradshaw, M., Agarwal, V., Zou, J., Stewart, S.G., Duan, X., Lamb, R.N., Smith, S.M., Raston, C.L., Iyer, K.S., 2013. Biogenic production of palladium nanocrystals using microalgae and their immobilization on chitosan nanofibers for catalytic applications. RSC Advances 3: 1009-1012.

Fernández-Luqueño, F., Medina-Pérez, G., López-Valdez, F., Gutiérrez-Ramírez, R., Campos-Montiel, R.G., VázquezNúñez, E., Loera-Serna, S., Almaraz-Buendia, I., Del Razo-Rodríguez, O.E., Madariaga-Navarrete, A., 2018. Use of Agronanobiotechnology in the Agro-Food Industry to Preserve Environmental Health and Improve the Welfare of Farmers. In: Agricultural Nanobiotechnology. López-Valdez, F., Fernández-Luqueño, F. (Eds.). Springer, Cham. pp. 3-16.

Fraceto, L.F., Grillo, R., de Medeiros, G.A., Scognamiglio, V., Rea, G., Bartolucci, C., 2016. Nanotechnology in agriculture: Which innovation potential does it have? Frontiers in Environmental Science 4:20.

Fulekar, J., Dutta, D.P., Pathak, B., Fulekar, M.H., 2018. Novel microbial and root mediated green synthesis of Ti02 nanoparticles and its application in wastewater remediation. Journal of Chemical Technology \& Biotechnology 93: 736-743.

Furgal, K.M., Meyer, R.L., Bester, K., 2015. Removing selected steroid hormones, biocides and pharmaceuticals from water by means of biogenic manganese oxide nanoparticles in situ at ppb levels. Chemosphere 136: 321-326.

Ganapathy Selvam, G., Sivakumar, K., 2015. Phycosynthesis of silver nanoparticles and photocatalytic degradation of methyl orange dye using silver (Ag) nanoparticles synthesized from Hypnea musciformis (Wulfen) J.V. Lamouroux. Applied Nanoscience 5: 617-622.

Ghazaryan, K., Movsesyan, H., Gevorgyan, A., Minkina, T., Sushkova, S., Rajput, V., Mandzhieva, S., 2020. Comparative hydrochemical assessment of groundwater quality from different aquifers for irrigation purposes using IWQI: A case-study from Masis province in Armenia. Groundwater for Sustainable Development 11: 100459.

Ghazaryan, K.A., Movsesyan, H.S., Khachatryan, H.E., Ghazaryan, N.P., Minkina, T.M., Sushkova, S.N., Mandzhieva, S.S., Rajput, V.D., 2018. Copper phytoextraction and phytostabilization potential of wild plant species growing in the mine polluted areas of Armenia. Geochemistry: Exploration, Environment, Analysis 19: 155-163.

Ghazaryan, K.A., Movsesyan, H.S., Minkina, T.M., Sushkova, S.N., Rajput, V.D., 2019. The identification of phytoextraction potential of Melilotus officinalis and Amaranthus retroflexus growing on copper- and molybdenum-polluted soils. Environmental Geochemistry and Health 43: 1327-1335.

Gong, X., Huang, D., Liu, Y., Zeng, G., Wang, R., Wan, J., Zhang, C., Cheng, M., Qin, X., Xue, W., 2017. Stabilized nanoscale zerovalent iron mediated cadmium accumulation and oxidative damage of Boehmeria nivea (L.) Gaudich cultivated in cadmium contaminated sediments. Environmental Science \& Technology 51: 11308-11316.

Guerra, F.D., Attia, M.F., Whitehead, D.C., Alexis, F., 2018. Nanotechnology for environmental remediation: Materials and applications. Molecules 23(7): 1760.

Handy, R.D., von der Kammer, F., Lead, J.R., Hassellov, M., Owen, R., Crane, M., 2008. The ecotoxicology and chemistry of manufactured nanoparticles. Ecotoxicology 17: 287-314.

Hu, W., Culloty, S., Darmody, G., Lynch, S., Davenport, J., Ramirez-Garcia, S., Dawson, K.A., Lynch, I., Blasco, J., Sheehan, D., 2014. Toxicity of copper oxide nanoparticles in the blue mussel, Mytilus edulis: a redox proteomic investigation. Chemosphere 108: 289-299.

Huang, D., Qin, X., Peng, Z., Liu, Y., Gong, X., Zeng, G., Huang, C., Cheng, M., Xue, W., Wang, X., 2018. Nanoscale zero-valent iron assisted phytoremediation of $\mathrm{Pb}$ in sediment: Impacts on metal accumulation and antioxidative system of Lolium perenne. Ecotoxicology and Environmental Safety 153: 229-237.

Ibrahim, R.K., Hayyan, M., AlSaadi, M.A., Hayyan, A., Ibrahim, S., 2016. Environmental application of nanotechnology: air, soil, and water. Environmental Science and Pollution Research 23: 13754-13788.

Jiang, D., Zeng, G., Huang, D., Chen, M., Zhang, C., Huang, C., Wan, J., 2018. Remediation of contaminated soils by enhanced nanoscale zero valent iron. Environmental Research 163: 217-227.

Jin, Y., Liu, W., Li, X., Shen, S.G., Liang, S.X., Liu, C., Shan, L., 2016. Nano-hydroxyapatite immobilized lead and enhanced plant growth of ryegrass in a contaminated soil. Ecological Engineering 95: 25-29. 
Jindrova, E., Chocova, M., Demnerova, K., Brenner, V., 2002. Bacterial aerobic degradation of benzene, toluene, ethylbenzene and xylene. Folia Microbiologica 47: 83-93.

Joshi, A., Kanthaliya, B., Rajput, V., Minkina, T., Arora, J., 2020. Assessment of phytoremediation capacity of three halophytes: Suaeda monoica, Tamarix indica and Cressa critica. Biologia Futura 71: 301-312.

Juárez-Maldonado, A., Ortega-Ortíz, H., Morales-Díaz, A.B., González-Morales, S., Morelos-Moreno, Á., Cabrera-De la Fuente, M., Sandoval-Rangel, A., Cadenas-Pliego, G., Benavides-Mendoza, A., 2019. Nanoparticles and Nanomaterials as Plant Biostimulants. International Journal of Molecular Sciences 20(1): 162.

Juwarkar, A.A., Singh, S.K., Mudhoo, A., 2010. A comprehensive overview of elements in bioremediation. Reviews in Environmental Science and Bio/Technology 9: 215-288.

Kang, J., Duan, X., Wang, C., Sun, H., Tan, X., Tade, M.O., Wang, S., 2018. Nitrogen-doped bamboo-like carbon nanotubes with $\mathrm{Ni}$ encapsulation for persulfate activation to remove emerging contaminants with excellent catalytic stability. Chemical Engineering Journal 332: 398-408.

Kanwar, V.S., Sharma, A., Srivastav, A.L., Rani, L., 2020. Phytoremediation of toxic metals present in soil and water environment: a critical review. Environmental Science and Pollution Research 27: 44835-44860.

Kaur, R., Bhatti, S.S., Singh, S., Singh, J., Singh, S., 2018. Phytoremediation of heavy metals using cotton plant: A field analysis. Bulletin of Environmental Contamination and Toxicology 101: 637-643.

Khan, S.H., Pathak, B., 2020. Zinc oxide based photocatalytic degradation of persistent pesticides: A comprehensive review. Environmental Nanotechnology, Monitoring \& Management 13: 100290.

Kharissova, O.V., Dias, H.V.R., Kharisov, B.I., Pérez, B.O., Pérez, V.M.J., 2013. The greener synthesis of nanoparticles. Trends in Biotechnology 31(4): 240-248.

Kim, Y.M., Murugesan, K., Chang, Y.Y., Kim, E.J., Chang, Y.S., 2012. Degradation of polybrominated diphenyl ethers by a sequential treatment with nanoscale zero valent iron and aerobic biodegradation. Journal of Chemical Technology and Biotechnology 87: 216-224.

Kolesnikov, S., Tsepina, N., Minnikova, T., Kazeev, K., Mandzhieva, S., Sushkova, S., Minkina, T., Mazarji, M., Singh, R.K., Rajput, V.D., 2021. Influence of silver nanoparticles on the biological indicators of Haplic chernozem. Plants 10(5): 1022.

Konnova, S.A., Lvov, Y.M., Fakhrullin, R.F., 2016. Nanoshell assembly for magnet-responsive oil-degrading bacteria. Langmuir 32: 12552-12558.

Koul, B., Poonia, A.K., Yadav, D., Jin, J.O., 2021. Microbe-mediated biosynthesis of nanoparticles: Applications and future prospects. Biomolecules 11(6): 886.

Koul, B., Taak, P., 2018. Biotechnological strategies for effective remediation of polluted soils. Springer, Singapore, $240 \mathrm{p}$.

Kranjc, E., Drobne, D., 2019. Nanomaterials in plants: A review of hazard and applications in the agri-food sector. Nanomaterials 9(8): 1094.

Kulkarni, M., Chaudhari, A., 2007. Microbial remediation of nitro-aromatic compounds: an overview. Journal of Environmental Management 85: 496-512.

Kumar, H., Sinha, S.K., Goud, V.V., Das, S., 2019. Removal of Cr(VI) by magnetic iron oxide nanoparticles synthesized from extracellular polymeric substances of chromium resistant acid-tolerant bacterium Lysinibacillus sphaericus RTA-01. Journal of Environmental Health Science and Engineering 17: 1001-1016.

Kumar, P., Kumar, A., Kumar, R., 2021. Phytoremediation and Nanoremediation. In: New frontiers of nanomaterials in environmental science. Kumar, R., Kumar, R., Kaur, G. (Eds.). Springer Singapore. pp. 281-297.

Kumari, A., Kumari, P., Rajput, V.D., Sushkova, S.N., Minkina, T., 2021. Metal(loid) nanosorbents in restoration of polluted soils: geochemical, ecotoxicological, and remediation perspectives. Environmental Geochemistry and Health (In press).

Kumari, V., Tripathi, A.K., 2020. Remediation of heavy metals in pharmaceutical effluent with the help of Bacillus cereus-based green-synthesized silver nanoparticles supported on alumina. Applied Nanoscience 10: 1709-1719.

Le, T.T., Nguyen, K.H., Jeon, J.R., Francis, A.J., Chang, Y.S., 2015. Nano/bio treatment of polychlorinated biphenyls with evaluation of comparative toxicity. Journal of Hazardous Materials 287: 335-341.

Li, H., Chi, Z., Yan, B., 2019. Long-term impacts of graphene oxide and Ag nanoparticles on anammox process: Performance, microbial community and toxic mechanism. Journal of Environmental Sciences 79: 239-247.

Liang, J., Yang, Z., Tang, L., Zeng, G., Yu, M., Li, X., Wu, H., Qian, Y., Li, X., Luo, Y., 2017. Changes in heavy metal mobility and availability from contaminated wetland soil remediated with combined biochar-compost. Chemosphere 181: 281-288.

Litvinov, Y., Shipkova, G., Rajput, V., Bakoyev, S., Sushkova, S., Mandzhieva, S., Minkina, T., Mischenko, N., Kalinichenko, V., Endovitsky, A., Batukaev, A., 2017. Cadmium status in chernozem of the Krasnodar Krai (Russia) after the application of phosphogypsum. Proceedings of the Estonian Academy of Sciences 66: 501-515.

Liu, L., Li, W., Song, W., Guo, M., 2018a. Remediation techniques for heavy metal-contaminated soils: Principles and applicability. Science of The Total Environment 633: 206-219.

Liu, W., Zuo, Q., Zhao, C., Wang, S., Shi, Y., Liang, S., Zhao, C., Shen, S., 2018b. Effects of Bacillus subtilis and nanohydroxyapatite on the metal accumulation and microbial diversity of rapeseed (Brassica campestris L.) for the remediation of cadmium-contaminated soil. Environmental Science and Pollution Research 25: 25217-25226. 
Lv, Y., Niu, Z., Chen, Y., Hu, Y., 2017. Bacterial effects and interfacial inactivation mechanism of nZVI/Pd on Pseudomonas putida strain. Water Research 115: 297-308.

Martins, M., Mourato, C., Sanches, S., Noronha, J.P., Crespo, M.T.B., Pereira, I.A.C., 2017. Biogenic platinum and palladium nanoparticles as new catalysts for the removal of pharmaceutical compounds. Water Research 108: 160-168.

Mboyi, A.V., Kamika, I., Momba, M.B., 2017. Detrimental effects of commercial zinc oxide and silver nanomaterials on bacterial populations and performance of wastewater systems. Physics and Chemistry of the Earth, Parts $A / B / C$ 100: 158-169.

Midhat, L., Ouazzani, N., Hejjaj, A., Ouhammou, A., Mandi, L., 2019. Accumulation of heavy metals in metallophytes from three mining sites (Southern Centre Morocco) and evaluation of their phytoremediation potential. Ecotoxicology and Environmental Safety 169: 150-160.

Minkina, T., Rajput, V., Fedorenko, G., Fedorenko, A., Mandzhieva, S., Sushkova, S., Morin, T., Yao, J., 2019. Anatomical and ultrastructural responses of Hordeum sativum to the soil spiked by copper. Environmental Geochemistry and Health 42: 45-58.

Moameri, M., Khalaki, M.A., 2019. Capability of Secale montanum trusted for phytoremediation of lead and cadmium in soils amended with nano-silica and municipal solid waste compost. Environmental Science and Pollution Research 26: 24315-24322.

Modi, S., Pathak, B., Fulekar, M., 2015. Microbial synthesized silver nanoparticles for decolorization and biodegradation of azo dye compound. Journal of Environmental Nanotechnology 4: 37-46.

Momeni, S., Nabipour, I., 2015. A simple green synthesis of palladium nanoparticles with Sargassum Alga and their electrocatalytic activities towards hydrogen peroxide. Applied Biochemistry and Biotechnology 176: 1937-1949.

Nancharaiah, Y.V., Dodge, C., Venugopalan, V.P., Narasimhan, S.V., Francis, A.J., 2010. Immobilization of Cr(VI) and its reduction to $\mathrm{Cr}$ (III) phosphate by granular biofilms comprising a mixture of microbes. Applied and Environmental Microbiology 76: 2433-2438.

Navarro, E., Baun, A., Behra, R., Hartmann, N.B., Filser, J., Miao, A.J., Quigg, A., Santschi, P.H., Sigg, L., 2008. Environmental behavior and ecotoxicity of engineered nanoparticles to algae, plants, and fungi. Ecotoxicology 17: 372-386.

Nzila, A., Razzak, S.A., Zhu, J., 2016. Bioaugmentation: An emerging strategy of industrial wastewater treatment for reuse and discharge. International Journal of Environmental Research and Public Health 13(9): 846

Oyewole, O., Raji, R., Musa, I., Enemanna, C., Abdulsalam, O., Yakubu, J., 2019. Enhanced degradation of crude oil with Alcaligenes faecalis ADY25 and iron oxide nanoparticle. International Journal of Applied Biological Research 10: 62-72.

Pang, Y., Zeng, G.M., Tang, L., Zhang, Y., Liu, Y.Y., Lei, X.X., Wu, M.S., Li, Z., Liu, C., 2011. Cr(VI) reduction by Pseudomonas aeruginosa immobilized in a polyvinyl alcohol/sodium alginate matrix containing multi-walled carbon nanotubes. Bioresource Technology 102: 10733-10736.

Paterlini, P., Romero, C.M., Alvarez, A., 2021. Application of Bio-Nanoparticles in Biotechnological Process Focusing in Bioremediation. In: Rhizobiont in Bioremediation of Hazardous Waste. Kumar, V., Prasad, R., Kumar, M. (Eds.). Springer Singapore, pp. 115-130.

Patil, S.S., Shedbalkar, U.U., Truskewycz, A., Chopade, B.A., Ball, A.S., 2016. Nanoparticles for environmental clean-up: A review of potential risks and emerging solutions. Environmental Technology \& Innovation 5: 10-21.

Patra, J.K., Baek, K.H., 2014. Green nanobiotechnology: Factors affecting synthesis and characterization techniques. Journal of Nanomaterials Article ID 417305.

Patra Shahi, M., Kumari, P., Mahobiya, D., Kumar Shahi, S., 2021. Chapter 4 - Nano-bioremediation of environmental contaminants: applications, challenges, and future prospects. In: Bioremediation for Environmental Sustainability. Kumar, V., Saxena, G., Shah, M.P. (Eds.). Elsevier. pp. 83-98.

Paul, D., Pandey, G., Pandey, J., Jain, R.K., 2005. Accessing microbial diversity for bioremediation and environmental restoration. Trends in Biotechnology 23: 135-142.

Penell, J., Lind, L., Salihovic, S., van Bavel, B., Lind, P.M., 2014. Persistent organic pollutants are related to the change in circulating lipid levels during a 5 year follow-up. Environmental Research 134: 190-197.

Pillai, H.P.S., Kottekottil, J., 2016. Nano-phytotechnological remediation of endosulfan using zero valent iron nanoparticles. Journal of Environmental Protection 7(5): 734-744.

Raj, R., Dalei, K., Chakraborty, J., Das, S., 2016. Extracellular polymeric substances of a marine bacterium mediated synthesis of CdS nanoparticles for removal of cadmium from aqueous solution. Journal of Colloid and Interface Science 462: 166-175.

Rajput, V.D., Minkina, T., Sushkova, S., Tsitsuashvili, V., Mandzhieva, S., Gorovtsov, A., Nevidomskyaya, D., Gromakova, N., 2017a. Effect of nanoparticles on crops and soil microbial communities. Journal of Soils and Sediments 18: 2179-2187.

Rajput, V.D., Minkina, T., Suskova, S., Mandzhieva, S., Tsitsuashvili, V., Chapligin, V., Fedorenko, A., 2017b. Effects of copper nanoparticles (CuO NPs) on crop plants: a Mini review. BioNanoScience 8: 36-42.

Rajput, V.D., Minkina, T., Fedorenko, A., Tsitsuashvili, V., Mandzhieva, S., Sushkova, S., Azarov, A., 2018. Metal oxide nanoparticles: Applications and effects on soil ecosystems. In: Soil Contamination: Sources, Assessment and Remediation. Lund, J.E. (Ed.). Nova Publishers. pp. 81-106. 
Rajput, V., Chaplygin, V., Gorovtsov, A., Fedorenko, A., Azarov, A., Chernikova, N., Barakhov, A., Minkina, T., Maksimov, A., Mandzhieva, S., Sushkova, S., 2020a. Assessing the toxicity and accumulation of bulk- and nano-CuO in Hordeum sativum L. Environmental Geochemistry and Health 43: 2443-2454.

Rajput, V., Minkina, T., Ahmed, B., Sushkova, S., Singh, R., Soldatov, M., Laratte, B., Fedorenko, A., Mandzhieva, S., Blicharska, E., Musarrat, J., Saquib, Q., Flieger, J., Gorovtsov, A., 2020b. Interaction of Copper-Based Nanoparticles to Soil, Terrestrial, and Aquatic Systems: Critical Review of the State of the Science and Future Perspectives. In: Reviews of Environmental Contamination and Toxicology Volume 252 de Voogt, P. (Ed.). Springer International Publishing, Cham. pp. 51-96.

Rajput, V., Minkina, T., Semenkov, I., Klink, G., Tarigholizadeh, S., Sushkova, S., 2020c. Phylogenetic analysis of hyperaccumulator plant species for heavy metals and polycyclic aromatic hydrocarbons. Environmental Geochemistry and Health 43: 1629-1654.

Rajput, V., Minkina, T., Sushkova, S., Behal, A., Maksimov, A., Blicharska, E., Ghazaryan, K., Movsesyan, H., Barsova, N., 2020d. ZnO and $\mathrm{CuO}$ nanoparticles: a threat to soil organisms, plants, and human health. Environmental Geochemistry and Health 42: 147-158.

Rajput, V.D., Minkina, T., Fedorenko, A., Chernikova, N., Hassan, T., Mandzhieva, S., Sushkova, S., Lysenko, V., Soldatov, M.A., Burachevskaya, M., 2021a. Effects of zinc oxide nanoparticles on physiological and anatomical indices in spring barley tissues. Nanomaterials 11(7): 1722.

Rajput, V.D., Minkina, T., Kumari, A., Harish, Singh, V.K., Verma, K.K., Mandzhieva, S., Sushkova, S., Srivastava, S., Keswani, C., 2021b. Coping with the challenges of abiotic stress in plants: new dimensions in the field application of nanoparticles. Plants 10(6): 1221.

Rajput, V.D., Singh, A., Singh, V.K., Minkina, T.M., Sushkova, S., 2021c. Chapter 4 - Impact of nanoparticles on soil resource. In: Nanomaterials for soil remediation. Amrane, A., Mohan, D., Nguyen, T.A., Assadi, A.A., Yasin, G. (Eds.). Elsevier. pp. 65-85.

Ramakrishna, M., Babu, D.R., Gengan, R.M., Chandra, S., Rao, G.N., 2016. Green synthesis of gold nanoparticles using marine algae and evaluation of their catalytic activity. Journal of Nanostructure in Chemistry 6: 1-13.

Reddy, K.R., Khodadoust, A.P., Darko-Kagya, K., 2014. Transport and Reactivity of Lactate-Modified Nanoscale Iron Particles for Remediation of DNT in Subsurface Soils. Journal of Environmental Engineering 140: 04014042.

Rizwan, M., Singh, M., Mitra, C.K., Morve, R.K., 2014. Ecofriendly application of nanomaterials: nanobioremediation. Journal of Nanoparticles Article ID 431787.

Romeh, A.A., Saber, R.A.I., 2020. Green nano-phytoremediation and solubility improving agents for the remediation of chlorfenapyr contaminated soil and water. Journal of Environmental Management 260: 110104.

Salvadori, M.R., Ando, R.A., Oller Nascimento, C.A., Corrêa, B., 2015. Extra and intracellular synthesis of nickel oxide nanoparticles mediated by dead fungal biomass. PLOS ONE 10(6): e0129799.

San Keskin, N.O., Celebioglu, A., Uyar, T., Tekinay, T., 2015. Microalgae immobilized by nanofibrous web for removal of reactive dyes from wastewater. Industrial \& Engineering Chemistry Research 54: 5802-5809.

Sangwan, S., Dukare, A., 2018. Microbe-mediated bioremediation: An eco-friendly sustainable approach for environmental clean-up. In: Advances in soil microbiology: Recent trends and future prospects: Volume 1: SoilMicrobe Interaction. Adhya, T.K., Lal, B., Mohapatra, B., Paul, D., Das, S. (Eds.). Springer Singapore. pp. $145-163$.

Sarwar, N., Imran, M., Shaheen, M.R., Ishaque, W., Kamran, M.A., Matloob, A., Rehim, A., Hussain, S., 2017. Phytoremediation strategies for soils contaminated with heavy metals: Modifications and future perspectives. Chemosphere 171: 710-721.

Sathyavathi, S., Manjula, A., Rajendhran, J., Gunasekaran, P., 2014. Extracellular synthesis and characterization of nickel oxide nanoparticles from Microbacterium sp. MRS-1 towards bioremediation of nickel electroplating industrial effluent. Bioresource Technology 165: 270-273.

Seshadri, S., Saranya, K., Kowshik, M., 2011. Green synthesis of lead sulfide nanoparticles by the lead resistant marine yeast, Rhodosporidium diobovatum. Biotechnology Progress 27: 1464-1469.

Sharma, K., Singh, G., Singh, G., Kumar, M., Bhalla, V., 2015. Silver nanoparticles: facile synthesis and their catalytic application for the degradation of dyes. RSC Advances 5: 25781-25788.

Shende, S.S., Rajput, V.D., Gorovtsov, A.V., Harish, Saxena, P., Minkina, T.M., Chokheli, V.A., Jatav, H.S., Sushkova, S.N., Kaur, P., Kizilkaya, R., 2021. Interaction of nanoparticles with microbes. In: Plant-microbes-engineered nanoparticles (PM-ENPs) Nexus in agro-ecosystems: Understanding the interaction of plant, microbes and engineered nano-particles (ENPS). Singh, P., Singh, R., Verma, P., Bhadouria, R., Kumar, A., Kaushik, M. (Eds.). Springer International Publishing, Cham. pp. 175-188.

Singh, J., Lee, B.K., 2016. Influence of nano- $\mathrm{TiO}_{2}$ particles on the bioaccumulation of Cd in soybean plants (Glycine max): a possible mechanism for the removal of $\mathrm{Cd}$ from the contaminated soil. Journal of Environmental Management 170: 88-96.

Singh, R., Behera, M., Kumar, S., 2020. Nano-bioremediation: An Innovative remediation technology for treatment and management of contaminated sites. In: Bioremediation of industrial waste for environmental safety: Volume II: Biological Agents and Methods for Industrial Waste Management. (Bharagava, R.N., Saxena, G. (Eds.). Springer Singapore. pp. 165-182.

Singh, R., Manickam, N., Mudiam, M.K.R., Murthy, R.C., Misra, V., 2013. An integrated (nano-bio) technique for degradation of $\gamma$-HCH contaminated soil. Journal of Hazardous Materials 258-259: 35-41. 
Sinha, S., Chattopadhyay, P., Pan, I., Chatterjee, S., Chanda, P., Bandyopadhyay, D., Das, K., Sen, S.K., 2009. Microbial transformation of xenobiotics for environmental bioremediation. African Journal of Biotechnology 8: 6016-6027.

Song, B., Xu, P., Chen, M., Tang, W., Zeng, G., Gong, J., Zhang, P., Ye, S., 2019. Using nanomaterials to facilitate the phytoremediation of contaminated soil. Critical Reviews in Environmental Science and Technology 49: $791-824$.

Subramaniyam, V., Subashchandrabose, S.R., Thavamani, P., Megharaj, M., Chen, Z., Naidu, R., 2015. Chlorococcum sp. MM11-a novel phyco-nanofactory for the synthesis of iron nanoparticles. Journal of Applied Phycology 27: 1861-1869.

Sun, Y.P., Li, X.Q., Cao, J., Zhang, W.X., Wang, H.P., 2006. Characterization of zero-valent iron nanoparticles. Advances in Colloid and Interface Science 120: 47-56.

Sushkova, S., Deryabkina, I., Antonenko, E., Kizilkaya, R., Rajput, V., Vasilyeva, G., 2018. Benzo[a]pyrene degradation and bioaccumulation in soil-plant system under artificial contamination. Science of The Total Environment 633: 13861391.

Sushkova, S., Minkina, T., Deryabkina, I., Mandzhieva, S., Zamulina, I., Bauer, T., Vasilyeva, G., Antonenko, E., Rajput, V., Kizılkaya, R., 2016. Features of accumulation, migration, and transformation of benzo[a]pyrene in soil-plant system in a model condition of soil contamination. Journal of Soils and Sediments 18: 2361-2367.

Sushkova, S.N., Minkina, T., Deryabkina, I., Mandzhieva, S., Zamulina, I., Bauer, T., Vasilyeva, G., Antonenko, E., Rajput, V., 2017. Influence of PAH contamination on soil ecological status. Journal of Soils and Sediments 18: 2368-2378.

Suvith, V.S., Philip, D., 2014. Catalytic degradation of methylene blue using biosynthesized gold and silver nanoparticles. Spectrochimica Acta Part A: Molecular and Biomolecular Spectroscopy 118: 526-532.

Tan, W., Peralta-Videa, J.R., Gardea-Torresdey, J.L., 2018. Interaction of titanium dioxide nanoparticles with soil components and plants: current knowledge and future research needs - a critical review. Environmental Science: Nano 5: 257-278.

Torimiro, N., Daramola, O.B., Oshibanjo, O.D., Otuyelu, F.O., Akinsanola, B.A., Yusuf, O.O., Ore, O.T., Omole, R.K., 2021. Ecorestoration of heavy metals and toxic chemicals in polluted environment using microbe-mediated nanomaterials. International Journal of Environmental Bioremediation \& Biodegradation 9: 8-21.

Tratnyek, P.G., Johnson, R.L., 2006. Nanotechnologies for environmental cleanup. Nano Today 1(2): 44-48.

Van Hamme Jonathan, D., Singh, A., Ward Owen, P., 2003. Recent advances in petroleum microbiology. Microbiology and Molecular Biology Reviews 67: 503-549.

Vaseashta, A., Vaclavikova, M., Vaseashta, S., Gallios, G., Roy, P., Pummakarnchana, 0., 2007. Nanostructures in environmental pollution detection, monitoring, and remediation. Science and Technology of Advanced Materials 8: 47-59.

Vázquez-Núñez, E., Molina-Guerrero, C.E., Peña-Castro, J.M., Fernández-Luqueño, F., de la Rosa-Álvarez, M.G., 2020. Use of nanotechnology for the bioremediation of contaminants: A review. Processes 8(7): 826.

Vijayan, S.R., Santhiyagu, P., Singamuthu, M., Kumari Ahila, N., Jayaraman, R., Ethiraj, K., 2014. Synthesis and characterization of silver and gold nanoparticles using aqueous extract of seaweed, Turbinaria conoides, and their antimicrofouling activity. The Scientific World Journal Article ID 938272.

Vítková, M., Puschenreiter, M., Komárek, M., 2018. Effect of nano zero-valent iron application on As, Cd, Pb, and Zn availability in the rhizosphere of metal(loid) contaminated soils. Chemosphere 200: 217-226.

Wang, H., Kim, B., Wunder, S.L., 2015. Nanoparticle-supported lipid bilayers as an in situ remediation strategy for hydrophobic organic contaminants in soils. Environmental Science \& Technology 49: 529-536.

Wang, L., Zhang, C., Gao, F., Mailhot, G., Pan, G., 2017a. Algae decorated $\mathrm{TiO}_{2} / \mathrm{Ag}$ hybrid nanofiber membrane with enhanced photocatalytic activity for $\operatorname{Cr}(\mathrm{VI})$ removal under visible light. Chemical Engineering Journal 314: 622630.

Wang, P.T., Song, Y.H., Fan, H.C., Yu, L., 2018. Bioreduction of azo dyes was enhanced by in-situ biogenic palladium nanoparticles. Bioresource Technology 266: 176-180.

Wang, R., Wang, S., Tai, Y., Tao, R., Dai, Y., Guo, J., Yang, Y., Duan, S., 2017b. Biogenic manganese oxides generated by green algae Desmodesmus sp. WR1 to improve bisphenol A removal. Journal of Hazardous Materials 339: 310 319.

Wang, X., Zhang, D., Pan, X., Lee, D.J., Al-Misned, F.A., Mortuza, M.G., Gadd, G.M., 2017c. Aerobic and anaerobic biosynthesis of nano-selenium for remediation of mercury contaminated soil. Chemosphere 170: 266-273.

Wani, R.A., Ganai, B.A.M., Shah, A., Uqab, B., 2017. Heavy metal uptake potential of aquatic plants through phytoremediation technique-a review. Journal of Bioremediation \& Biodegradation 8(4): 1000404.

Weelink, S.A.B., van Eekert, M.H.A., Stams, A.J.M., 2010. Degradation of BTEX by anaerobic bacteria: physiology and application. Reviews in Environmental Science and Bio/Technology 9: 359-385.

Wu, R., Wu, H., Jiang, X., Shen, J., Faheem, M., Sun, X., Li, J., Han, W., Wang, L., Liu, X., 2017. The key role of biogenic manganese oxides in enhanced removal of highly recalcitrant 1, 2, 4-triazole from bio-treated chemical industrial wastewater. Environmental Science \& Pollution Research 24: 10570-10583.

Wuana, R.A., Okieimen, F.E., 2011. Heavy metals in contaminated soils: A review of sources, chemistry, risks and best available strategies for remediation. ISRN Ecology Article ID 402647.

Yan, W., Lien, H.L., Koel, B.E., Zhang, W.X., 2013. Iron nanoparticles for environmental clean-up: recent developments and future outlook. Environmental Science: Processes \& Impacts 15: 63-77. 
Yaqoob, A.A., Parveen, T., Umar, K., Mohamad Ibrahim, M.N., 2020. Role of nanomaterials in the treatment of wastewater: A Review. Water 12(2): 495.

Yousefi, N., Emtyazjoo, M., Sepehr, M.N., Darzi, S.J., Sepahy, A.A., 2020. Green synthesis of Pseudomonas aeruginosa immobilized $\mathrm{Fe}_{3} \mathrm{O}_{4}$-multiwalled carbon nanotubes bio-adsorbent for the removal of 2,4,6-trinitrophenol from aqueous solution. Environmental Technology \& Innovation 20: 101071.

Zamani, N., Mehrpour, O., Hassanian-Moghaddam, H., Jalali, M., Amirabadizadeh, A., Samie, S., Sabeti, S., Kolahi, A.A., 2020. A preliminary report on the largest ongoing outbreak of lead toxicity in Iran. Scientific Reports 10: 11797.

Zand, A. D., Tabrizi, A.M., 2020. Effect of zero-valent iron nanoparticles on the phytoextraction ability of Kochia scoparia and its response in Pb contaminated soil Environmental Engineering Research 26(4): 200227.

Zhang, C., Li, M., Xu, X., Liu, N., 2015. Effects of carbon nanotubes on atrazine biodegradation by Arthrobacter sp. Journal of Hazardous Materials 287: 1-6.

Zhao, J., Wu, T., Wu, K., Oikawa, K., Hidaka, H., Serpone, N., 1998. Photoassisted degradation of dye pollutants. 3. Degradation of the cationic dye Rhodamine $\mathrm{B}$ in aqueous anionic surfactant $/ \mathrm{TiO}_{2}$ dispersions under visible light irradiation: Evidence for the need of substrate adsorption on $\mathrm{TiO}_{2}$ particles. Environmental Science \& Technology 32: 2394-2400.

Zhu, N., Zhang, B., Yu, Q., 2020. Genetic engineering-facilitated coassembly of synthetic bacterial cells and magnetic nanoparticles for efficient heavy metal removal. ACS Applied Materials \& Interfaces 12: 22948-22957.

Zhu, Y., Liu, X., Hu, Y., Wang, R., Chen, M., Wu, J., Wang, Y., Kang, S., Sun, Y., Zhu, M., 2019. Behavior, remediation effect and toxicity of nanomaterials in water environments. Environmental Research 174: 54-60. 